\title{
SENSORY EVALUATION AND SURVIVAL OF PROBIOTICS IN MODIFIED BANANA FLOUR YOGHURT DURING STORAGE
}

\author{
[Evaluasi Sensori dan Sintasan Probiotik dalam Yoghurt Tepung Pisang Modifikasi selama Penyimpanan]
}

\author{
Betty Sri Laksmi Suryaatmadja Jenie ${ }^{1)^{*}}$, Muhamad Yusup Saputra ${ }^{2)}$ dan Widaningrum ${ }^{3)}$ \\ 1) Department of Food Science \& Technology, Bogor Agricultural University, Bogor \\ 2) Alumnus of Department of Food Science \& Technology, Bogor Agricultural University, Bogor \\ 3) Indonesian Center for Agricultural Post Harvest Research \& Development, Ministry of Agriculture, Bogor
}

Accepted May $08^{\text {th }} 2013$ / Approved July $08^{\text {th }} 2013$

\begin{abstract}
Modified uli banana flour (MUBF) rich in resistant starch as prebiotic source was formulated in yoghurt making to substitute skim milk at various concentrations i.e. 40,50,60, and 70\%. Yoghurts were prepared using Lactobacillus bulgaricus and Streptococcus thermophilus as the starter cultures. The objective of this study was to determine the maximum MUBF concentration to produce yoghurt with good sensory quality and good number of surviving probiotics (Bifidobacterium bifidum and Lactobacillus plantarum BSL) in non-pasteurized and pasteurized $\left(90^{\circ} \mathrm{C}, 30\right.$ minutes) MUBF yoghurt during 4 week of storage at $10^{\circ} \mathrm{C}$. Hedonic rating and ranking test on yoghurt attributes (aroma, taste, consistency, texture, color and overall preference) performed by 35 untrained panelists showed that yoghurt produced with $70 \%$ MUBF substitution achieved good preferences in all of the attributes ranging from neutral to like. The $\mathrm{pH}$ value of the product decreased with increase in MUBF concentration. In addition, titratable acidity (TA), expressed as \% lactic acid, increased. Survival of both probiotics in 70\% MUBF yoghurt either in the pasteurized synbiotic or nonpasteurized yoghurts were still relatively high at week 4 . The yoghurt still contains $10^{8} \mathrm{CFU} / \mathrm{ml}$ of lactic acid bacteria, although this was a log decrease from the initial count. Therefore, the MUBF yoghurt was promising as synbiotic yoghurt based on the probiotic counts throughout 4 week of storage, which was higher than the minimum level recommended $\left(10^{6} \mathrm{CFU} / \mathrm{ml}\right)$ to provide the beneficial effect.
\end{abstract}

Keywords: banana flour, Bifidobacterium bifidum, Lactobacillus plantarum, survival of probiotic, yoghurt

\begin{abstract}
ABSTRAK
Tepung pisang uli modifikasi (TPUM) kaya akan pati resisten sebagai sumber prebiotik diformulasikan dalam pembuatan yoghurt untuk mensubstitusi susu skim pada berbagai konsentrasi (40, 50, 50 dan 70\%). Yoghurt dibuat menggunakan Lactobacillus bulgaricus dan Streptococcus thermophilus sebagai kultur starter. Tujuan dari penelitian ini adalah untuk menentukan konsentrasi TPUM maksimum yang dapat menghasilkan yoghurt dengan mutu sensori yang baik dan survival probiotik (Bifidobacterium bifidum dan Lactobacillus plantarum BSL) dalam yoghurt TPUM non-pasteurisasi dan pasteurisasi $\left(90^{\circ} \mathrm{C}, 30\right.$ menit) selama penyimpanan 4 minggu pada suhu $10^{\circ} \mathrm{C}$. Hasil uji sensori (hedonic rating dan ranking) oleh 35 panelis tidak terlatih menunjukkan bahwa yoghurt yang dibuat dengan substitusi TPUM sebesar $70 \%$ memperoleh kesukaan yang baik terhadap semua atribut mutu (aroma, rasa, konsistensi, tekstur, warna dan overall) berkisar dari netral sampai suka. Nilai pH produk menurun dengan naiknya konsentrasi TPUM, sedangkan total asam tertitrasi (TAT) yang dinyatakan sebagai \% asam laktat meningkat. Viabilitas kedua strain probiotik dalam 70\% yoghurt TPUM selama penyimpanan 4 minggu menunjukkan bahwa jumlah probiotik (jumlah bakteri asam laktat) baik dalam yoghurt TPUM non-pasteurisasi maupun pasteurisasi masih relatif tinggi (108 CFU/ml) pada minggu ke 4, walaupun terjadi penurunan sekitar satu unit log. Oleh karena itu, yoghurt TPUM dipertimbangkan cukup menjanjikan untuk dikembangkan sebagai yoghurt sinbiotik berdasarkan jumlah probiotik selama penyimpanan 4 minggu masih lebih tinggi dari konsentrasi yang direkomendasikan (106 CFU/ml) untuk memberikan manfaat kesehatan.
\end{abstract}

Kata kunci: Bifidobacterium bifidum, Lactobacillus plantarum, sintasan probiotik, tepung pisang, yoghurt

\section{INTRODUCTION}

Indonesia is rich in natural resources including banana that has a potential as carbohydrate source for food consumption. Banana is also known as source of vitamins (provitamin A, B, and $\mathrm{C}$ ) and minerals (potassium, magnesium, phosphor, iron,

Paper Presented at International Conference on "Future of Food Factors", October 3-4, 2012, Jakarta, Indonesia.

${ }^{*}$ Corresponding Author:

Email : betty_jenie@yahoo.com; Phone: (0251) 8620517 and calcium) which are important to health. Banana is an unseasonal fruit and is easily found during the whole year. Banana is abundant in the market. Effort to process bananas especially the plantain type into flour form had been conducted (Saguilan et al. 2005; Sajilata et al. 2006). There are several varieties of plantain found in Indonesia such as tanduk and uli. Uli is a plantain variety which has high contents of starch and amilose. According to Sajilata et al. (2006), starch with high amylose content is potential to be developed to commercial resistant starch. Jenie et al. (2010a) had developed a process 
that modify uli banana flour which was rich in resistant starch (RS).

Probiotics and prebiotics are examples of functional foods that received much attention in recent years. Functional foods are foods that may provide a health benefit beyond basic nutrition (Miletić et al. 2008). Functional food provides benefits to one or more of the target of body functions as well as nutrient that enable to strengthen the mechanism of body's defense, so it could decrease the risk of disease (Roberfroid, 2007). Probiotics are living microorganisms which in the sufficient quantities could provide health benefits for the host (Robertson et al. 2005). Lactic acid bacteria including strains of Lactobacillus and Bifidobacterium are known as potential probiotics. Kusumawati et al. (2003) reported that Lactobacillus plantarum 28sa (L. plantarum BSL) had an activity to lower serum cholesterol in rats. Probiotics also have a potential role as antihypertensive, immune modulator, hypocholesterolemic and perimenopousal treatment (Liong, 2007). Bifidobacterium bifidum was also reported to reduce apoptosis in the intestinal epithelium in necrotizing enterocolitis (Khailova et al. 2010).

Prebiotic is a selectively fermented ingredient that allows specific changes, both in the composition and/or activity in the gastrointestinal microflora that confers benefits upon host wellbeing and health (Roberfroid, 2007). RS can be considered as a prebiotic and has shown beneficial effects in disease preventions including modulation of glycemic index (GI), diabetes, cholesterol lowering capability, and weight management (Thakorlal et al. 2010). RS Type III increased the counts of Bifidobacteria (has bifidogenic properties) after testing on human (Bouhnik et al. 2004). Maize and RS enriched breads could reduce postprandial glycemic responses (Brites et al. 2011), while RS of beans reduce the serum cholesterol concentration in rats (Han et al. 2003). Other sources such as cereals, legumes tubers and unripe banana have attracted much attention recently due to its prebiotic potential activity (Niba and Rose, 2003). Modified uli banana flour (MUBF) rich in RS had been successfully produced through spontaneous fermentation-autoclaving-cooling process (Jenie et al. 2010a). The MUBF had been further examined for its prebiotics potency by growing probiotic bacteria using media containing MUBF as substrate. The results showed that the MUBF performed prebiotic activity by supporting the growth of the tested probiotic candidates (Jenie et al. 2012). RS rich-MUBF had been applied into various foods such as prebiotic cookies, steamed brownies and bread (Jenie et al. 2010 ${ }^{b}$ ). It is also a potential ingredient to be incorporated into synbiotic yoghurt.

Synbiotic food is a food that contains synergistic prebiotic and probiotic. Substances present in prebiotics can be used by probiotics as a carbon source or energy source in the colon to support the growth of probiotic, while pathogen will be suppressed. Application of the mixture (prebiotics and probiotics) in synbiotic food is useful for the host due to its function in supporting the availability and survival of probiotics in adequate quantities in the digestive tract, so that it can decrease the growth of pathogens (Hamayouni et al. 2008). Synbiotic food products which have already found in the market are milk, yoghurt, cheese, and ice cream.
In developing a synbiotic product, the type of probiotics and the quantity of prebiotics should be considered. Besides its effectivity as a functional food, synbiotic product should also give acceptable sensory quality including aroma, texture, taste, and color. The objectives of this study were to determine the maximum MUBF concentration that can be incorporated into yoghurt formula as milk substitute and to evaluate the survival of two probiotic strains (B. bifidum and L. plantarum BSL) during refrigerated storage $\left(10^{\circ} \mathrm{C}\right)$.

\section{MATERIALS AND METHODS}

\section{Materials}

Raw materials used were uli plantain variety purchased at a local market in Bogor. Degree of ripeness of banana was mature with green skin. Other materials used were ingredients for yoghurt making such as skim milk and sugar.

Bacterial cultures used in this study were yoghurt starter cultures (Lactobacillus bulgaricus and Streptococcus thermophilus) and probiotic cultures i.e. L. plantarum BSL (Food Microbiology Laboratory, Department of Food Science and Technology, IPB) and Bifidobacterium bifidum (Food and Nutrition Culture Collection (FNCC), Gajahmada University).

\section{Preparation of modified uli banana flour}

Uli banana flour was prepared according to modification process developed by Jenie et al. (2010a), comprised of spontaneous fermentation of banana slices, followed by autoclaving-cooling process. The fruits were peeled, cut into 6 $\mathrm{mm}$ slices, and soaked in sterile aquadest at ratio of $3: 4$ (banana : aquadest). Fermentation of the banana slices were carried out spontaneously for 24 hour in $1000 \mathrm{~mL}$ of erlenmeyer flask contained $375 \mathrm{~g}$ of banana slices and $500 \mathrm{ml}$ of aquadest. Banana slices were drained and autoclaved at $121^{\circ} \mathrm{C}$ for $15 \mathrm{~min}$ and allowed to cool at room temperature and kept in the refrigerator $\left(10^{\circ} \mathrm{C}\right)$ for $24 \mathrm{~h}$. Banana slices were then dried in the oven at $50^{\circ} \mathrm{C}$ for approximately $30 \mathrm{~h}$ until the moisture content reached $12 \%$. The dried banana slices were ground using a disc mill and sieved through 100 mesh of siever. The MUBF obtained was analyzed for resistant starch content following the procedure of Englyst et al. (1992) and ready to be incorporated into the yoghurt mix.

\section{Preparation of MUBF yoghurt}

Various MUBF concentrations (40,50, 60 and $70 \%$ ) were incorporated into yoghurt formula as milk substitute. MUBF yoghurt mixtures were pasteurized at $90^{\circ} \mathrm{C}$ for 30 minute and allowed to cool until $40^{\circ} \mathrm{C}$. Five percent of yoghurt starter cultures Lactobacillus bulgaricus and Streptococcus thermophillus (1:1) were then inoculated into MUBF yoghurt mix and incubated at $37^{\circ} \mathrm{C}$ for 24 hour. Yoghurt produced were analyzed for its $\mathrm{pH}$, titratable acidity (expressed as \% lactic acid), and sensory evaluation. Yoghurt formula contained maximum concentration of MUBF that still produced yoghurt with good sensory properties according to the results of sensory evaluation test will be used further to study the survival of probiotics in MUBF yoghurt during refrigerated storage. 


\section{Synbiotic MUBF yoghurt}

The best formula of MUBF yoghurt resulted from the above experiment was used in this study. The MUBF yoghurt was divided into two parts, the first part was pasteurized at $90^{\circ} \mathrm{C}$ for 30 minute in order to inactivate the yoghurt cultures and the second part was unpasteurized. Two strains of probiotic candidates i.e. L. plantarum BSL, and B. bifidum were added into each part of yoghurt at the concentration of $10^{9} \mathrm{cfu} / \mathrm{ml}$ and then stored in the refrigerator $\left(10^{\circ} \mathrm{C}\right)$ for 4 weeks (wk). Survival of the probiotics, $\mathrm{pH}$ and total titratable acidity of MUBF yoghurt were measured every week.

\section{Determination of $\mathrm{pH}$}

The $\mathrm{pH}$ of the MUBF yoghurt samples were measured at 0 , 1, 2, 3 and 4 wk of storage. The electrode was caliberated with $\mathrm{pH} 4.00$ and 7.00 buffer solutions prior to use.

\section{Determination of titratable acidity}

Titratable acidity of the MUBF yoghurt was determined using AOAC method (1999) with slight modification. MUBF yoghurt samples were weighed $(10 \mathrm{~g})$, added with aquadest until $100 \mathrm{~mL}$ using volumetric flask and filtered with paper filter. Twenty five $\mathrm{ml}$ of filtrate was added with $1 \%$ phenolphthalein and titrated with $0.1 \mathrm{~N} \mathrm{NaOH}$ (standardized with potassium hydrogen phthalate) until pink colour was formed. Titratable acidity of the samples were calculated and expressed as \% lactic acid.

\section{Analysis of RS content (Englyst et al. 1992)}

MUBF sample was first prepared to eliminate fat and simple sugars (reducing sugars) by washing it with $85 \%$ ethanol (ratio of MUBF:85\% ethanol was 1:2), filtered and sun dried. One $g$ of fat and simple sugars free MUBF was mixed in $20 \mathrm{ml}$ of sodium acetate buffer $(0.1 \mathrm{M}, \mathrm{pH} 5.2)$, cooked in water bath for 30 minute, cooled to $37^{\circ} \mathrm{C}$, mixed with enzyme solution $(5 \mathrm{ml})$ consisting of pancreatin extracts and amiloglucosidase enzyme (AMG), then incubated in waterbath at $37^{\circ} \mathrm{C}$. Pancreatin extracts was prepared by suspending $3 \mathrm{~g}$ of pancreatin in $20 \mathrm{ml}$ of deionized water, stirred for $10 \mathrm{~min}$ at room temperature, and centrifuged at $1500 \mathrm{~g}$ for $10 \mathrm{~min}$. Enzyme solution was prepared by mixing $13.5 \mathrm{ml}$ of supernatant of pancreatin extract, $210 \mathrm{U}$ AMG, and $1 \mathrm{ml}$ of deionized water. Rapidly digestible starch (RDS) is expressed as the total starch digested during the first 20 minute, and slowly digestible starch (SDS) is expressed as the total starch digested between duration of 20 and $120 \mathrm{~min}$. $\mathrm{KOH}(10 \mathrm{M})$ then added to the starch dispersion and stored at $0^{\circ} \mathrm{C}$ for $15 \mathrm{~min}$. AMG was added to the dispersion and incubated in water bath at $70^{\circ} \mathrm{C}$ for 30 minutes to obtain RS.

The RS content was calculated as follows:

$\%$ RS $=100 \% \times$ (total starch - RDS - SDS) $(g, d s b) /$ total starch $(g, d s b)$

Total starch was analysed according to AOAC (1999).

\section{Sensory evaluation of MUBF yoghurt}

Sensory evaluation of MUBF yoghurt was carried out by applying hedonic rating and ranking tests (Adawiyah and Waysima, 2009). Yoghurt samples were presented in coded cups and evaluated by 35 untrained panelists. The panelists were asked to score the liking degrees (five scales) of yoghurt attributes including aroma, taste, texture, and color and overall liking.

\section{Determination of probiotic counts}

Enumeration of the probiotic counts in MUBF yoghurt was performed by pour plating the yoghurt samples in MRSA (de Man Rogosa and Sharpe agar, Oxoid). Anaerobic incubation was conducted at $37^{\circ} \mathrm{C}$ for 48 hour. Especially for B. bifidum, before incubation, the plates were put into anoxomat jar to provide oxygen free condition. Enumeration of bacterial counts was performed according to BAM (2001).

\section{Statistical analysis}

The data from duplicate trials were calculated with mean values and colony forming units (CFU) were converted to logarithmic values. Comparison of means was performed by analysis of variance (ANOVA) and the differences between samples were analysed for significance by running the Software SPSS 16.0 Production facility. Differences were considered as significant if $\mathrm{P}<0.05$.

\section{RESULTS AND DISCUSSION}

\section{Chemical composition of MUBF}

Results of chemical analysis of MUBF were shown in Table 1. MUBF produced had total starch $46.34 \%$ and RS content $14.82 \mathrm{~g} / 100 \mathrm{~g}$ of MUBF or $31.84 \mathrm{~g} / 100 \mathrm{~g}$ of starch. This result confirmed the previous study (Jenie et al. 2010a) that modification process consisted of 24 hour spontaneous fermentation followed by autoclaving-cooling process could increase the RS content of banana flour (15.24\%) compared to control sample $(6.38 \%)$ obtained without fermentation process.

\begin{tabular}{lc}
\multicolumn{2}{c}{ Table 1. Sugar and starch content of MUBF ( $\mathrm{g}$ dry matter) } \\
\hline Wnalysis & Concentration (\%) \\
\hline Water & $15.95 \pm 0.31$ \\
Sugar & $51.49 \pm 3.45$ \\
Total starch & $46.34 \pm 3.11$ \\
Rapid digestible starch & $25.85 \pm 3.00$ \\
SDS (Slowly digestible starch) & $5.68 \pm 1.74$ \\
RS (Resistant starch) & $14.82 \pm 2.81$ \\
\hline
\end{tabular}

\section{$\mathrm{pH}$ and titratable acidity}

The $\mathrm{pH}$ values of MUBF yoghurt were significantly $(P<0.05)$ affected by MUBF concentration (Table 2). The higher the concentration of MUBF used, the lower the $\mathrm{pH}$ of yoghurt would be. The $\mathrm{pH}$ of yoghurt control (without MUBF substitution) was 4.42 , while $\mathrm{pH}$ of yoghurt with $40,50,60$, and $700 \%$ substitution of MUBF were $3.90 ; 3.78 ; 3.76$; and 3.76 respectively. On the contrary, titratable acidity (TA) expressed as \% lactic acid of MUBF yoghurt were increase following the higher concentration of MUBF incorporated.

Fermentation by lactic acid bacteria produced lactic acid that can be derived from lactose (Robinson et al. 2006), amylose (Reddy et al. 2008) and glucose (Abdullah and Osman, 2010). Higher MUBF concentration provided more amylose and 
sugar that will be fermented by the yoghurt starter culture and produced more acids and lower the $\mathrm{pH}$ of MUBF yoghurt. The facts that $\mathrm{pH}$ decreased while TA of the yoghurt increased while increasing MUBF substitution suggested that the yoghurt starter culture might have amylolytic activity.

Table 2. Effect of MUBF substitution on $\mathrm{pH}$ and TA of MUBF yoghurt

\begin{tabular}{ccc}
\hline MUBF Substitution (\%) & $\mathrm{pH}$ & TA (\% Lactic Acid) \\
\hline 0 (control) & $4.42^{\mathrm{d}} \pm 0.01$ & $1.18^{\mathrm{a}} \pm 0.02$ \\
40 & $3.90^{\mathrm{c}} \pm 0.08$ & $1.63^{\mathrm{b}} \pm 0.06$ \\
50 & $3.78^{\mathrm{b}} \pm 0.05$ & $0.70^{\mathrm{c}} \pm 0.05$ \\
60 & $3.76^{\mathrm{b}} \pm 0.03$ & $1.71^{\mathrm{c}} \pm 0.05$ \\
70 & $3.70^{\mathrm{a}} \pm 0.00$ & $1.77^{\mathrm{d}} \pm 0.03$ \\
\hline
\end{tabular}

Means between rows for each column (pH and TA) with different letter superscripts are significantly different $(P<0.05)$

\section{Hedonic rating and hedonic ranking}

Effect of different MUBF substitutions on the MUBF yoghurt attributes (aroma, taste, consistency, texture, color, overall liking and hedonic ranking) are shown in Figure. 1, 2, 3, and 4. The MUBF substitution ranged between $40-70 \%$ did not affect significantly $(P>0.05)$ toward the aroma and taste as shown in Figure 1, while consistency, texture, color and overall liking of the yoghurt samples (Figure. 2 and 3), were significantly $(P<0.05)$ affected.
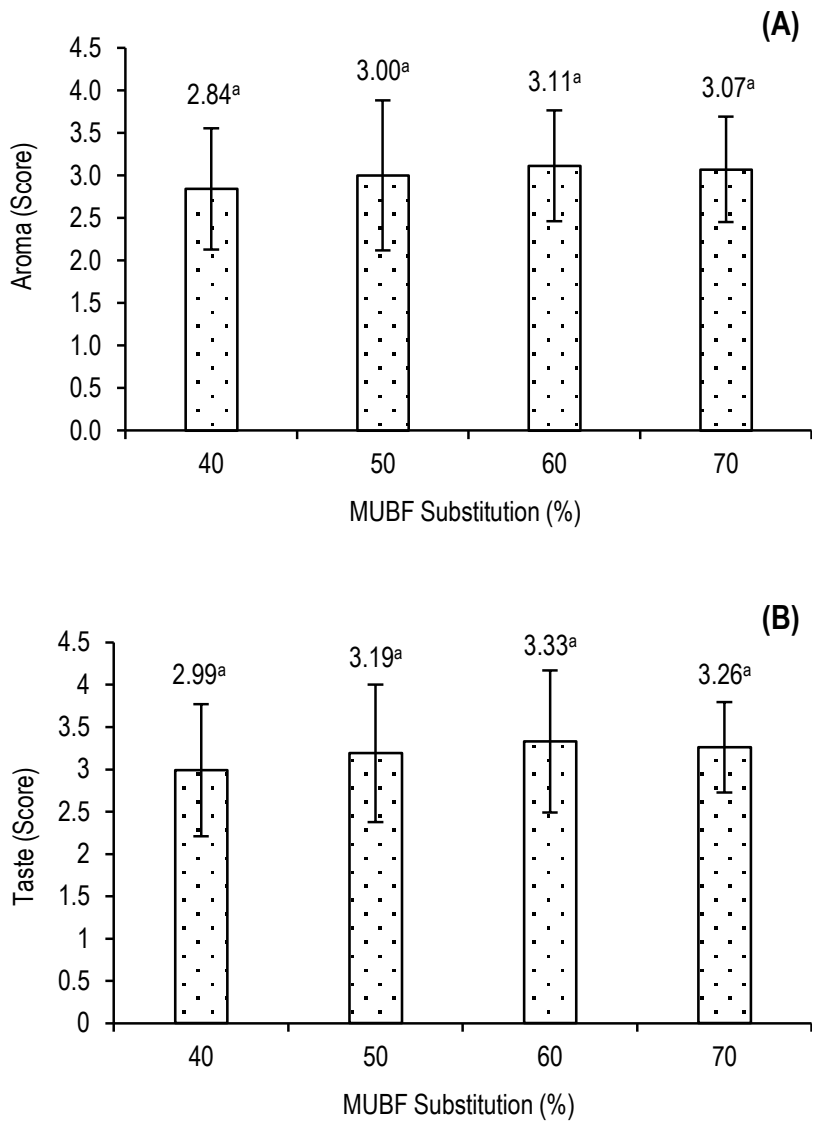

Figure 1. Effect of MUBF substitution on aroma $(A)$ and taste $(B)$ of MUBF yoghurt. Means with different letter superscripts are siginificantly different $(P<0.05)$
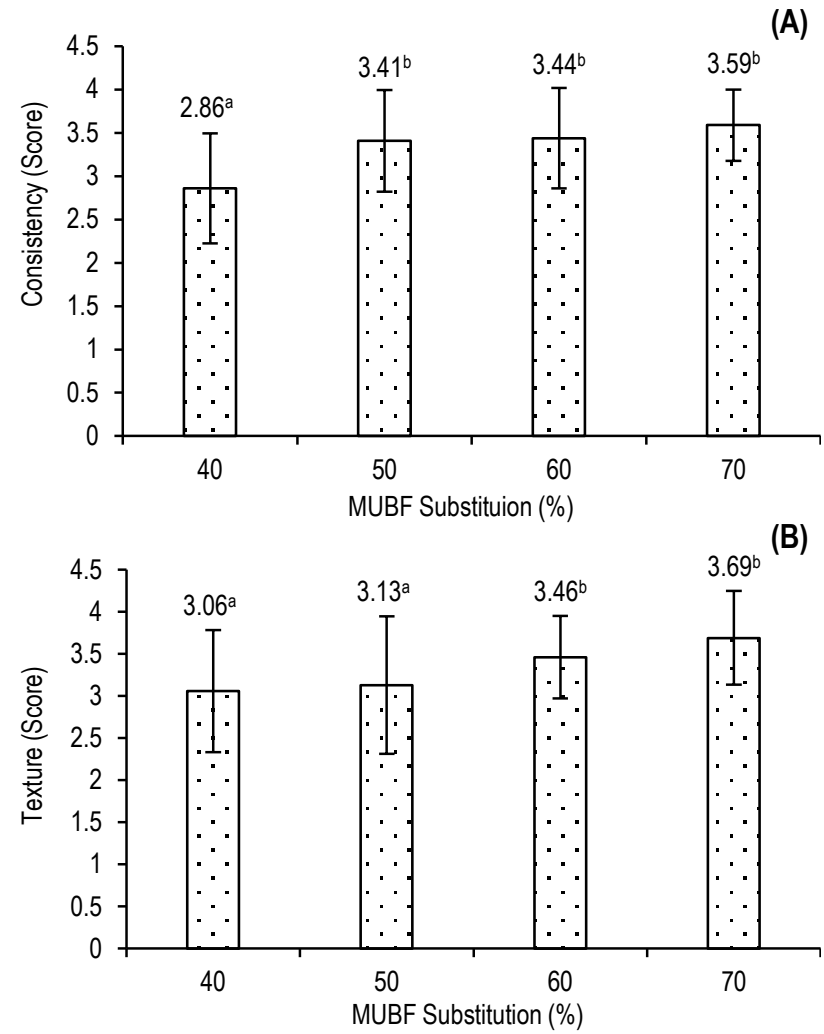

Figure 2. Effect of MUBF substitution on consistency $(A)$ and texture (B) of MUBF yoghurt. Means with different letter superscripts are siginificantly different $(P<0.05)$
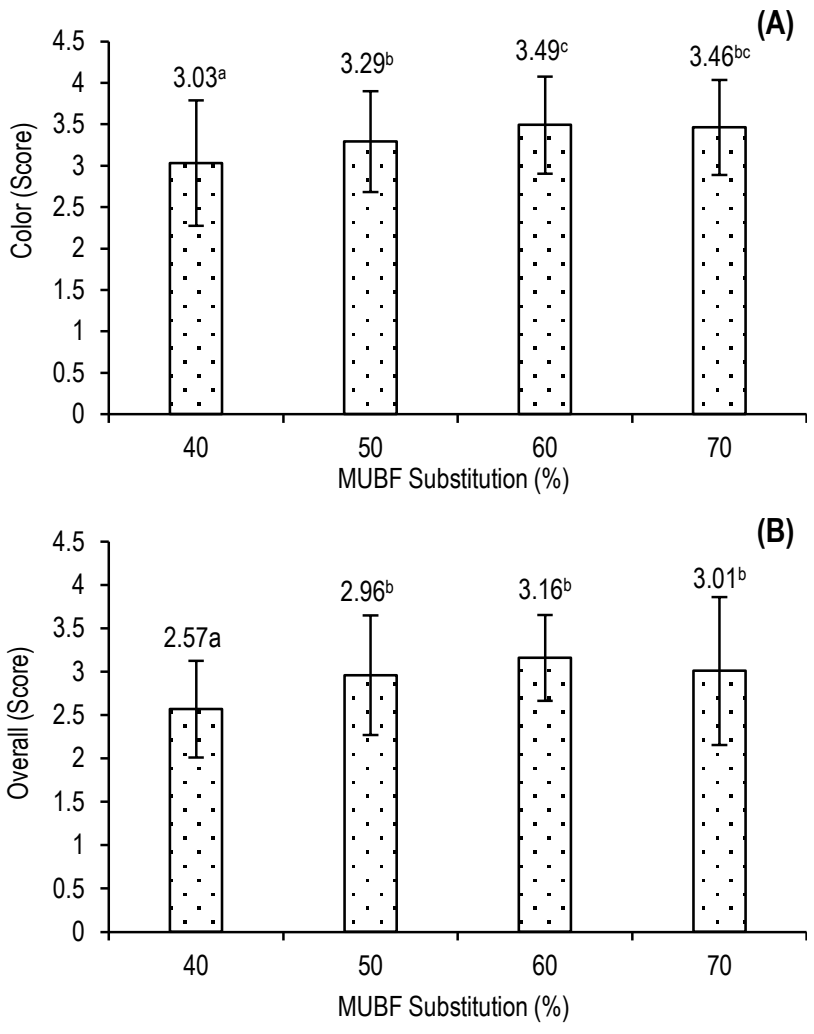

Figure 3. Effect of MUBF substitution on (A) color and (B) overall liking of MUBF yoghurt. Means with different letter superscripts are siginificantly different $(P<0.05)$ 
The increase of the MUBF concentration would darken the color of the yoghurt as the color of MUBF was yellowish to brown. However, the panelists apparently preferred the brown color derived from the higher MUBF substitution (60-70\%). In general, the scores for all attributes of yoghurt substituted with $50-70 \%$ MUBF were ranged 3-4 representing the levels of liking were between neutral (neither like nor dislike) and like. The results of hedonic ranking (Figure 4) on MUBF yoghurt with variation of the MUBF substitutions showed that the highest ranking was achieved by yoghurt with $70 \%$ (2.27) of MUBF. However, it was not significantly different $(P<0.05)$ with $50 \%$ and $60 \%$ substitution. The rank score was only significantly different toward $40 \%$ substitution.

Based on the above results, it is suggested that the MUBF could be incorporated into the yoghurt formula to substitute skim milk as high as $70 \%$. Theoretically, the higher the MUBF substitution incorporated in yoghurt formula, the higher the RS content will be in the product. This will bring beneficiary effects tobalance the prebiotic and probiotic contents in the synbiotic food system either during its shelf life (storage) or later in the digestive tract. This condition also would give the advantage mainly in providing higher assurance that the prebiotic properties of RS will still remain in considerable quantity in the product.

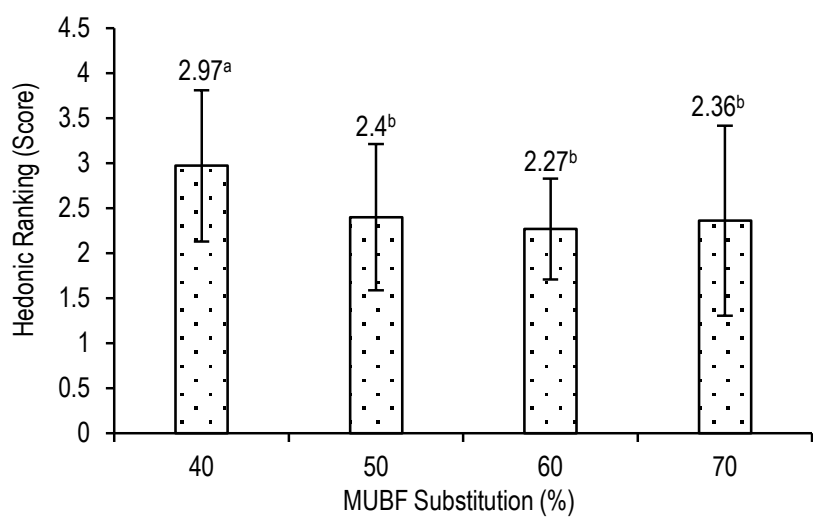

Figure 4. Effect of MUBF substitution on hedonic ranking of MUBF yoghurt. Means with different letter superscripts are siginificantly different $(P<0.05)$

\section{Probiotic survival in synbiotic yoghurt during storage}

For this study, yoghurt was prepared using $70 \%$ substitution of MUBF, the maximum concentration of MUBF which was still preferred by the panelists. Two types of MUBF yoghurt were prepared before the addition of probiotics i.e. pasteurized and non pasteurized. Pasteurization was aimed to inactivate the yoghurt starter cultures and observe the probiotic survival during 4 wk of storage without the presence of the starter cultures in the product. While the total counts in non pasteurized yoghurt was assumed as the total of probiotic counts plus yoghurt starter culture counts.

As shown in Table 3, both types of MUBF yoghurts (pasteurized and non pasteurized) either added with $L$. plantarum BSL or B. bifidum showed non significant $(P>0.05)$ difference in probiotic counts during 4 wk of storage. The LAB counts for pasteurized yoghurt clearly expressed the number of probiotic only since after pasteurization at $90^{\circ} \mathrm{C}$ for 30 minute there was no $L A B$ counts detected in the pasteurized yoghurt. While in the non pasteurized yoghurt the number of $L A B$ counts was the total counts of probiotic and yoghurt starter cultures. In this case, the result did not inform the survival of probiotics counts with the presence of starter cultures in the nonpasteurized yoghurt during storage. All enumerations of $L A B$ counts were carried out using the same MRSA media. From table 2, all types of $L A B$ including the yoghurt starter cultures and two strains of probiotics used in this study could grow well in this media. To enumerate the number of a specific LAB strain, Friedrich and Lenke (2006) develop a method called Multiplex Quantitative Real-Time PCR and flow cytometry-fluorescence by performing in-situ hybridization or FISH (Fluorescence In-Situ Hybridization) method.

Table 3. Survival of probiotics (B. bifidum and L. plantarum BSL) in synbiotic MUBF yoghurt during refrigerated storage

\begin{tabular}{|c|c|c|c|c|c|}
\hline \multirow{3}{*}{ Probiotic } & \multicolumn{5}{|c|}{ LAB Counts (log CFU/ml) } \\
\hline & \multicolumn{5}{|c|}{ Storage (weeks) } \\
\hline & 0 & 1 & 2 & 3 & 4 \\
\hline \multicolumn{6}{|l|}{ B. bifidum } \\
\hline Non- & $9.24^{a}$ & $9.22^{\mathrm{ab}}$ & $9.20^{\mathrm{abc}}$ & $9.00^{f} \pm$ & $8.18^{h}$ \\
\hline pasteurized & \pm 0.04 & \pm 0.05 & \pm 0.04 & 0.02 & \pm 0.03 \\
\hline \multirow[t]{2}{*}{ Pasteurized } & $9.17^{a b c}$ & $9.14^{\text {cde }}$ & $9.12^{\mathrm{de}}$ & $8.909 \pm$ & $8.08^{i}$ \\
\hline & \pm 0.04 & \pm 0.04 & \pm 0.02 & 0.03 & \pm 0.04 \\
\hline \multicolumn{6}{|c|}{ L. plantarum BSL } \\
\hline Non- & $9.21 \mathrm{abc}$ & $9.18^{\mathrm{abcd}}$ & $9.16^{\text {cde }}$ & $8.92^{g} \pm$ & $8.12^{\mathrm{hi}}$ \\
\hline pasteurized & \pm 0.02 & \pm 0.03 & \pm 0.02 & 0.01 & \pm 0.01 \\
\hline Pasteurized & $9.14^{\text {cde }}$ & $9.12^{\mathrm{de}}$ & $9.08 \mathrm{e}$ & $8.87 \mathrm{~g}$ & $8.06^{i}$ \\
\hline & \pm 0.01 & \pm 0.03 & \pm 0.05 & \pm 0.01 & \pm 0.03 \\
\hline
\end{tabular}

Means with different letter superscripts are significantly different $(\mathrm{P}<0.05)$

Storage time significantly $(P<0.05)$ affected the probiotic counts either for $B$. bifidum or L. plantarum BSL during storage. In general, all probiotic counts were quite stable (9.08-9.24 log CFU/ml) until wk 2 and then decreased significantly less than 1 $\log$ unit and about 1 log unit at wk 3 and wk 4, respectively. Similar results were also reported (Donkor et al. 2007) which found that probiotic (L. acidophilus L10 and $L$. casei $L 26$ ) concentrations in yoghurt decreased almost one log during 28 days of cold storage $\left(4^{\circ} \mathrm{C}\right.$ ). Addition of FOS (fructooligosaccharide) as prebiotic coud improve the viability of $B$. bifidum $\left(10^{7} \mathrm{CFU} / \mathrm{g}\right)$ at 21 days of storage better than control without prebiotic (Akalin et al. 2004). The decrease of probiotic viability was reported due to the acid injury of the bacteria (Talwalkar and Kailasapathy, 2004). Initial concentration of probiotic also affected the viability during storage. An excessively high Lactobacillus acidophilus inoculation level $(2.33 \mathrm{~g} / 100 \mathrm{~g})$ produced yoghurt with lower lactobacilli counts throughout storage and lower $L$. acidophilus counts from 4 to 7 wk of storage than the yoghurt inoculated with lower concentration (0.238 g/100 g) (Olson, 2008).

Both probiotic strains in this study could maintain their viabilities at concentrations $\left(10^{8} \mathrm{CFU} / \mathrm{ml}\right)$ higher than the recommended level $\left(10^{6} \mathrm{CFU} / \mathrm{ml}\right)$ until 4 wk of storage to provide the beneficial effect (Toma and Pokrotnieks, 2006; Sanders, 2008). This result suggested that the MUBF yoghurt was promising as synbiotic yoghurt based on the probiotic counts until wk 4 was still in considerable number. 


\section{Changes of $\mathrm{pH}$ and titratable acidity during storage}

During 4 wk of storage at $10^{\circ} \mathrm{C}$, changes of $\mathrm{pH}$ and titratable acidity (TA) of synbiotic MUBF yoghurt were observed (Figure. 5 and 6). Pasteurization of yoghurt, probiotic strains and storage significantly $(\mathrm{P}<0.05)$ affected the $\mathrm{pH}$ and $\mathrm{TA}$ of synbiotic yoghurt. The $\mathrm{pH}$ of synbiotic yoghurt showed increasing trend from wk 0 (3.58-3.68) to wk 4 (3.81-3.95), and the TA decreased over the storage period, indicating that there were no lactic acid produced during storage. This phenomenon was also supported by the decrease of probiotic counts during storage (Table 3). Different result was reported by Kailasapathy (2006) where the $\mathrm{pH}$ of skim milk based-yoghurt decreased during storage at $4^{\circ} \mathrm{C}$ for 6 wk of storage, suggesting that the yoghurt starter cultures were still active even at refrigerated temperature and could produce small amount of lactic acid from lactose. At present study, yoghurt was made by substituting $70 \%$ of skim milk in the formula with RS rich-MUBF. MUBF yoghurt contained more starch but less lactose than the skim milk yoghurt.
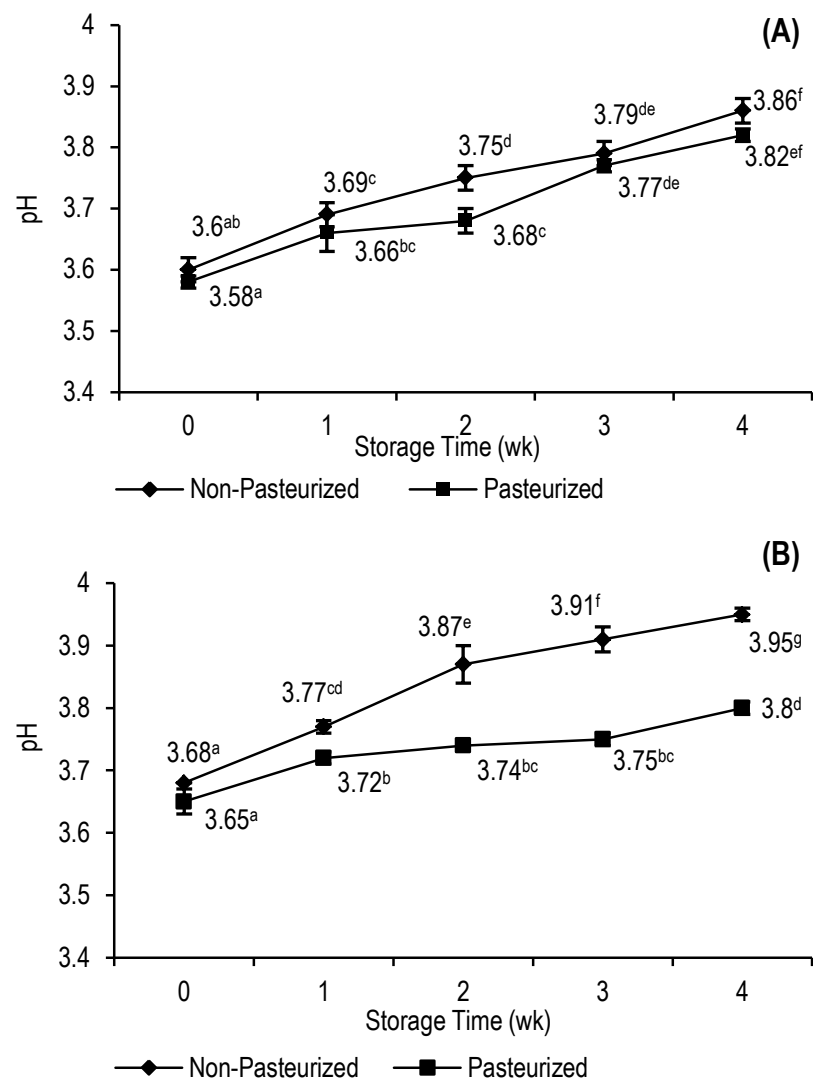

Figure 5. Changes of $p H$ of synbiotic yoghurt during storage: $(A)+L$. plantarum; $(\mathrm{B})+$ B. bifidum

The highest increase of $\mathrm{pH}$ (3.95) was observed in synbiotic non-pasteurized yoghurt containing B. bifidum. While lower increase of $\mathrm{pH}$ (3.81-3.82) was demonstrated by pasteurized yoghurt for both probiotics. This was probably due to pasteurization that was able to reduce yeast contaminant in the yoghurt.

Increasing of $\mathrm{pH}$ was in accordance with the decreasing of TA of synbiotic yoghurt (Figure 5 and 6 ). At initial storage, the
TA of synbiotic yoghurt were between 1.78-1.83\% then decreased to $1.60-1.75 \%$ at wk 4 of storage. Higher decrease of TA generally occurred in non pasteurized synbiotic yoghurt, except for synbiotic yoghurt with $L$. plantarum BSL, the decrease of TA was similar to non-pasteurized yoghurt.
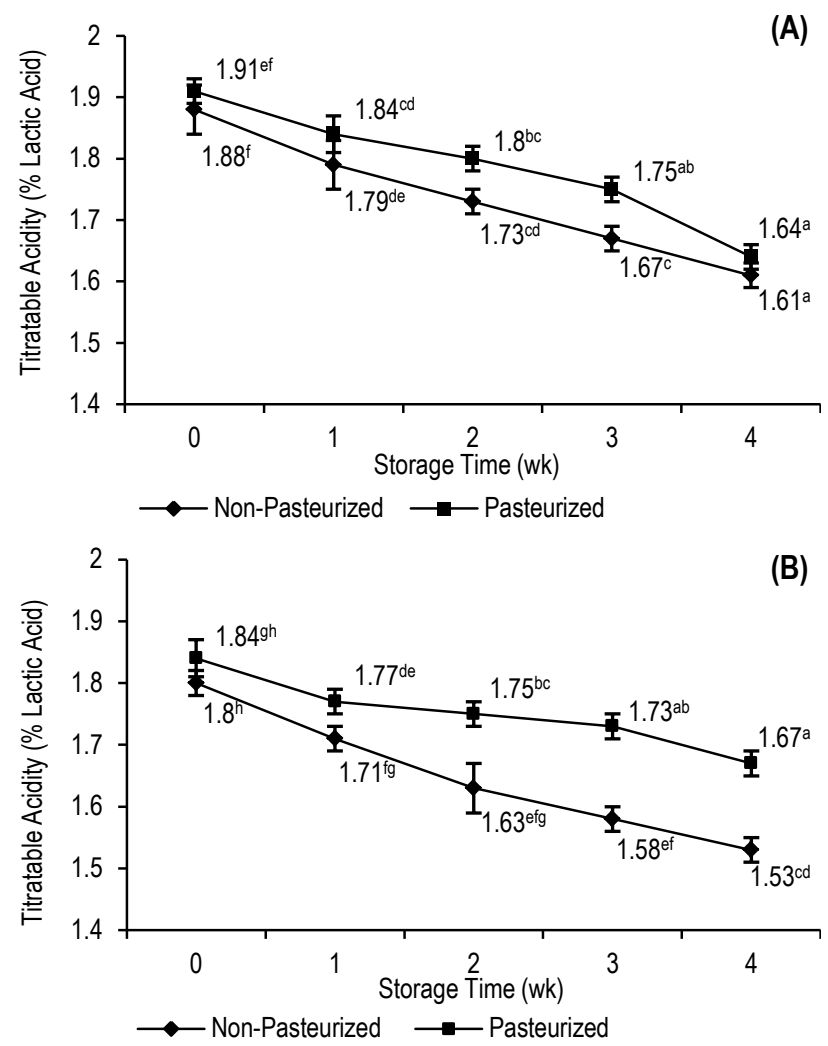

Figure 6. Changes of titratable acidity of synbiotic yoghurt during storage: $(A)+$ L. plantarum; $(B)+B$. bifidum

\section{CONCLUSION}

RS rich-MUBF was successfully incorporated in yoghurt formula as milk substitute at the maximum level of $70 \%$ and received good preferences for all yoghurt attributes (aroma, taste, consistency, texture, color and overall liking) ranging from neutral to like. Increasing MUBF substitution up to $70 \%$ resulted in increased panelists liking responses for texture and color of yoghurt. Probiotics maintained high viabilities in $70 \%$ MUBF synbiotic yoghurt during $2 \mathrm{wk}$ of storage at refrigerated temperature, but tend to decrease at approximately one log at wk 4 . The product is promising as a synbiotic yoghurt as shown by the relatively high probiotic counts $\left(10^{8} \mathrm{CFU} / \mathrm{ml}\right)$ either for $B$. bifidum or $L$. plantarum BSL during 4 wk of storage at $4^{\circ} \mathrm{C}$. However both probiotics strains retained their viabilities at high concentration $\left(10^{8} \mathrm{CFU} / \mathrm{ml}\right)$ and were considered be able to provide health benefits especially in the pasteurized yoghurt, since the probiotics counts were not encountered by the number of the yoghurt starter cutures. For non pasteurized yoghurt, the probiotics counts were total counts including the starter cutures. To enumerate the probiotics only while the starter cultures present in the MUBF synbiotic yoghurt needs more 
sophisticated method of analysis to confirm that the high counts were also attained by the probiotics with the presence of starter cultures.

\section{ACKNOWLEDGEMENT}

This work was funded by the KKP3T (Joint Partnership Agricultural Research with Higher Education) Project, between Center for Agricultural Postharvest Research and Development, Department of Agriculture and Bogor Agricultural University (IPB) year 2011.

\section{REFERENCES}

Adawiyah DR, Waysima. 2009. Sensory Evaluation of Food Products. Department of Food Science and Technology. Faculty of Agricultural Engineering and Technology. Bogor Agricultural University, IPB. Bogor.

Abdullah SA, Osman MM. 2010. Isolation and identification of lactic acid bacteria from raw cow milk, white cheese and rob in Sudan. Pak J Nutr 9: 1203-1206. DOI: 10.3923/pin. 2010.1203.1206.

Akalin AS, Fenderya S, Akbulut N. 2004. Viability and activity of bifidobacteria in yoghurt containing fructooligosaccharide during refrigerated storage. Int J Food Sci Tech 39: 613-621. DOI: 10.1111/j.1365-2621.2004.00829.x.

[AOAC] Association of Official Analytical Chemists. 1999. Official Methods of Analysis. Vol II $16^{\text {th }}$ ed. Association of Official Analytical Chemists, Washington, DC.

[BAM] Bacteriological Analytical Manual. 2001. Chapter 3: Aerobic Plate Count. U.S. Food and Drug Administration. www.fda.gov/Food/ScienceResearch/LaboratoryMethods/B acteriologicalAnalyticalManualBAM/ucm063346.html. [December 26th 2011].

Bouhnik Y, Raskine L, Simoneau G, Vicaut E, Neut C, Flourié B, Brouns F, Bornet FR. 2004. The capacity of nondigestible carbohydrates to stimulate fecal Bifidobacteria in healthy humans: a double-blind, randomized, placebo-controlled, parallel group, dose-response relation study. Am J Clin Nutr 80: 1658-1664.

Brites CM, Trigo MJ, Carrapiço B, Alviña M, Bessa RJ. 2011. Maize and resistant starch enriched breads reduce postprandial glycemic responses in rats. Nutr Res 31: 302308. DOI: 10.1016/j.nutres.2011.02.001.

Donkor ON, Nilmini SLI, Stolic P, Vasiljevic T, Shah NP. 2007. Survival and activity of selected probiotic organisms in settype yoghurt during cold storage. Int Dairy J 17: 657-665. DOI: 10.1016/j.idairyj.2006.08.006.

Englyst HN, Kingman SM, Cummings JH. 1992. Classification and measurement of nutritionally important starch fraction. Eur J Clin Nutr 46: 533-550.

Friedrich U, Lenke J. 2006. Improved enumeration of lactic acid bacteria in mesophilic dairy starter cultures by using multiplex quantitative real-time PCR and flow cytometry- fluorescence in situ hybridization. Appl Environ Microbiol 72: 4163-4171. DOI: 10.1128/AEM.02283-05.

Han KH, Fukushima M, Shimizu K, Kojima M, Ohba K, Tanaka A, Shimada K, Sekikawa M, Nakano M. 2003. Resistant starches of beans reduce the serum cholesterol concentration in rats. J Nutr Sci Vitaminol (Tokyo). 49: 281286.

Hamayouni A, Azizi A, Ehsani MR, Yarmand MS, Razavi SH. 2008. Effect of microencapsulation and resistant starch on the probiotic survival and sensory properties of synbiotic ice cream. Food Chem 111: 50-55. DOI: 10.1016/i.food chem.2008.03.036.

Jenie BSL, Kusumaningrum HD, Widowati S. 2010. Product Development of Resistant Starch Rich-Banana Flour as Functional Foods. Proceeding Seminar of IPB Research Results. Bogor Agricultural University.

Jenie BSL, Widowati S, Kusumaningrum HD. 2010 b. Bakery and Steamed Products Made of resistant Starch-Rich Banana Flour as Functional Foods. Abstract of Int. Conf. and Exhibition on Neutraceuticals and Functional Foods. Bali, Oct 11-15, 2010. Int Society for Neutraceuticals \& Functional Foods. p 105-118.

Jenie BSL, Widaningrum, Nur Richana, Suliantari. 2012. Prebiotic Potency of Resistant Starch Isolated from Uli Banana Flour Modified by Controlled FermentationAutoclaving-Cooling Process. Abstract of Int. Conf. Future of Food Factor. Association of Food Technologists (PATPI) and Seafast Center. IPB.

Kailasapathy K. 2006. Survival of free and encapsulated probiotic bacteria and their effect on the sensory properties of yoghurt. LWT-Food Sci Technol 39: 1221-1227. DOI: 10.1016/j.Iwt.2005.07.013.

Khailova L, Patrick SKM, Arganbright KM, Halpern MD, Kinouchi T, Dvorak B. 2010. Bifidobacterium bifidum reduces apoptosis in the intestinal epithelium in necrotizing enterocolitis. Am J Physiol Gastrointest Liver Physiol 299: G1118-G1127. DOI: 10.1152/ajpgi.00131.2010.

Kusumawati N, Jenie BSL, Setyahadi S, Dewanti R. 2003. Selection of indigenous lactic acid bacteria as probiotics for lowering serum cholesterol levels. J Mikrobiol Indonesia 8: 39-43.

Liong M. 2007. Probiotics: a critical review of their potential role as antihypertensives, immune modulator, hypocholesterolemics and perimenopousal treatments. Nutr Rev 65: 316-328.

Miletić I, Šobajić S, Đorđević B. 2008. Functional foods and their role in the improvement of health status. J Med Biochem 27: 367-370. DOI: 10.2478/v10011-008-0017-0.

Niba LL, Rose N. 2003. Effect of soaking solution concentration on resistant starch and oligosaccharide content of adzuki ( $V$. angularis), Fava (V. Faba), lima ( $P$. lunatus) and mung bean (V. radiata L.). J Food Technol 1: 4-8.

Olson DW, Aryana KJ. 2008. An excessively high Lactobacillus acidophilus inoculation level in yoghurt lowers product 
quality during storage. LWT-Food Sci Technol 41: 911-918. DOI: 10.1016/i.Iwt.2007.05.017.

Reddy G, Altaf MD, Naveena BJ, Venkateshwar M, Kumar EV. 2008. Amylolytic bacterial lactic acid fermentation-A review. Biotechnol Advances 26: 22-34. DOI: 10.1016/i.biotech adv.2007.07.004.

Roberfroid M. 2007. Prebiotics: The concept revisited. J Nutr 137: 830S-837S.

Robertson MD, Bickerton AS, Dennis AL, Vidal H, Frayn KN. 2005. Insulin-sensitizing effects of dietary resistant starch and effects on skeletal muscle and adipose tissue metabolism. Am J Clin Nut 82: 559-567.

Sajilata MG, Singhal RS, Kulkarni PR. 2006. Resistant starch a review. Comp Rev Food Sci F. 5: 1-17. DOI: 10.1111/j.1541 -4337.2006.tb00076.x.

Saguilan AA, Flores-Huicochea E, Tovar J, Garcia-Suarez F, Guiterres-Meraz F, Bello-Perez LA. 2005. Resistant starch- rich powder prepared by autoclaving of native and lintnerized banana starch: partial characterization. StarchStrake 57: 405-412. DOI: 10.1002/star.200400386.

Sanders ME. 2008. Probiotics: definition, sources, selection, and uses. Clin Infect Dis 46: S58-S61. DOI: 10.1086/523341.

Talwalkar A, Kailasapathy K. 2004. A review of oxygen toxicity in probiotic yoghurts: Influence on the probiotic bacteria and protective techniques. Comp Rev Food Sci F 3: 117-124. DOI: 10.1111/j.1541-4337.2004.tb00061.x.

Thakorlal J, Perera CO, Smith B, Englberger L, Lorens A. 2010. Resistant starch in micronesian banana cultivars offers health benefits. Pacific Health Dialog 16: 49-59.

Toma MM, Pokrotnieks J. 2006. Probiotics as functional food: microbiological and medical aspects. Acta Universitatis 710: $117-129$. 